\title{
Continuous Education in New Manufacturing Systems
}

\author{
M. Tazza, \\ CEFET-PR.CPGEI \\ Av. Sete de Setembro, 3165 \\ 80-230-901 Curitiba PR Brasil \\ fax: +55 (041) 2245070
}

\begin{abstract}
It will be described a case study in the context of Continuous Education in New Manufacturing Systems. In the case study the term New Manufacturing Systems will be restricted to Flexible Manufacturing Systems context. The term Continuous Education will be analyzed as one six years experience in teaching and researching activities at post-graduation level at the cefet-pr.cpgei. The education-research program has been developed by adapting the curriculum to the needs of the development of a software tool for the project and analysis of Flexible Manufacturing Systems at workstation level. By project it is intended the specification of the behavioral and structural characteristics of an FMS. The term analysis means a quantitative description of performance parameters: throughput, sub utilization index, induced wait times and mean value of pallet's population in storage buffers.
\end{abstract}

\section{Keywords}

Flexible Manufacturing Systems, Manufacturing Automation, Computer Integrated Manufacturing, Education in Automated Manufacturing

\section{INTRODUCTION}

The decade shows an increasing number of publications related with Manufacturing Automation in general and with Computer Integrated Manufacturing (CIM) and Flexible Manufacturing Systems (FMS) in particular. This growth is due to the proposition of some interesting problems to administrators, engineers and researcher community involved with the design, implementation and operation of complex automated manufacturing systems. Such problems are originated from the need of efficient answers to layout organization, group technology, scheduling and control questions. The term Flexible Manufacturing System is a general descritpion of a manufacturing system that is economically renewable when producing medium size number part types at medium sized volumes. Medium size can range from tenths to hundreds for part types and from thousands to tenths of thousands for production volumes. Fig-1 shows the production scope of FMS. 


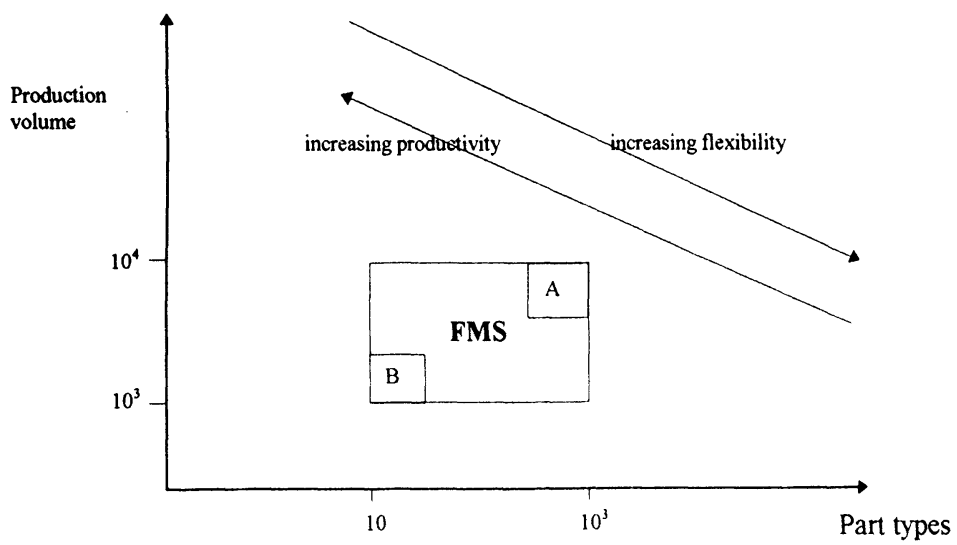

Fig-1: application scope of FMS

It must be noticed that the final values for the interval for volumes and number of part types are strongly related with manufacturing similarities of part types. In other words, a great number of different part types can be produced at high volumes (region A in Fig-1) if there is great similarity in parts process plans. Region B shows the situation of producing a small variety of part types with considerable differences among manufacturing plans.

The major goal of a manufacturing enterprise is to be price/quality competitive in the national and/or international industrial competition. The competitivity is reached by giving a correct solution to the technical-economical problems posed by the efficient implementation and control of large scale automated manufacturing system. The problems reach from controling perturbations in the communication system of the production environment to developing scheduling routines with real time capabilites. Although the application seems to be new, the technical tools for modeling and analysis purposes are based on well know theoretical aspects of computer science. The problems are normally reduced to large size matrix computation, real time monitoring of systems, efficient graph searching, resource allocation, concurrence and synchronization of processes.

We consider that the detailed analisys of production systems design alternatives is of primary importance for efficient final result. The paper describes the basic organization of a software tool (ANALYTICE) developed for the project and analysis of FMSs together with the resulting educational program. Both the tool and a recommended educational program will be detailed. The software is being developed at the Curso de Pos-Graduação em Engenharia Elétrica e Informática Industrial at CEFET-PR. Most of the implementation and some of the specification tasks has been carried on by under-and graduate students, sometimes as lectures tasks, sometimes as M.Sc. dissertation. Section 2 describes the principal organizational and functional characteristics of ANALYTICE. Section 3 describes and discusses the educational program developed for supporting the software tool. 


\section{THE SOFTWARE TOOL ANALYTICE}

The software development process started with a functional specification of the tool. The software should provide functions for the project and analysis of FMSs. An FMS is defined as a manufacturing system with some degree of flexibility in the manufacturing process. This flexibility is achieved by the use of NC-controlled machine-tools and automated material handling system equipment under the supervision of a control program. In our context, project means the specification of the structural and behavioral characteristics of the manufacturing environment. Analysis means the numerical description of relevant performance parameters of the manufacturing system when operating under the restrictions imposed by the project. The relevant parameters are those normally related with performance evaluation models: throughput, induced wait times, index of sub utilization of equipment, mean value of parts and pallets number in storage buffers, work in process, production costs. The restrictions imposed by a specific project represent the system's invariant for this design: number and type of NCmachine-tools and material handling equipment, number of pallets and fixtures, part families, layout, scheduling policies and control programs.

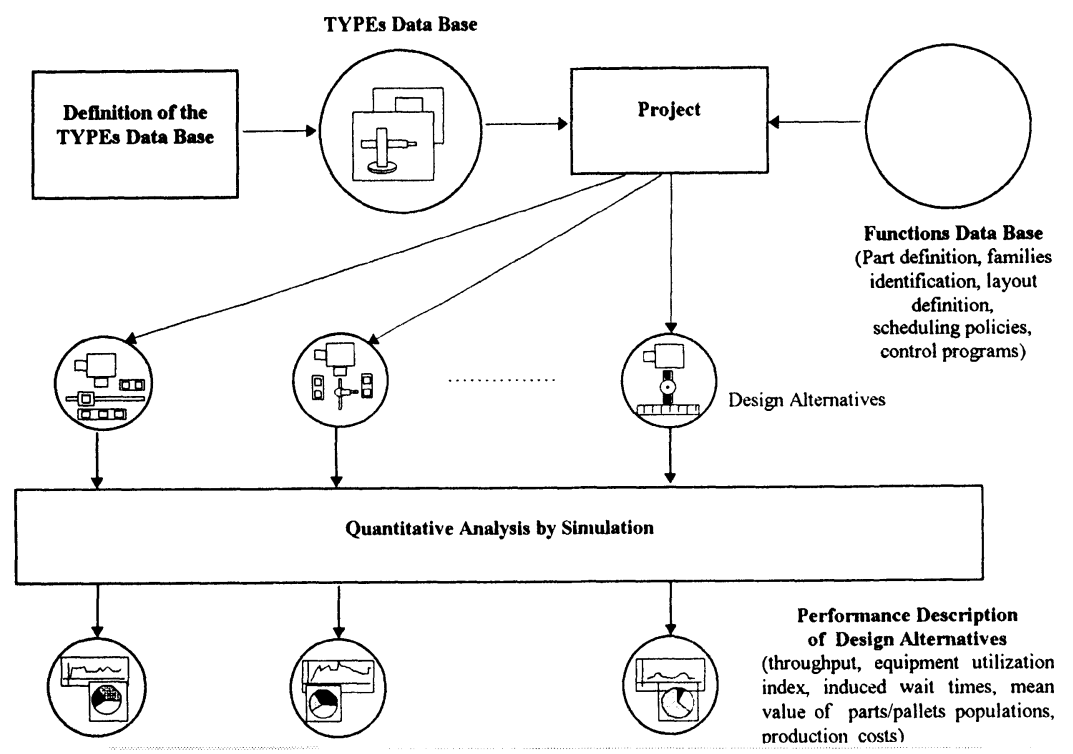

Fig-2: general functional organization ANALYTICE

\subsection{General System Organization}

The Definition of TYPEs Data Base environment in fig- 2 is supported by definition and validation modules that allow the structural and behavioral definition and validation of equipment. Starting from a mental model of an equipment or from a description of a real one the user builds an abstraction of the equipment in terms of <process $>$ s, <control signals $>$, 
<responses>, <monitoring variables>, <interaction interface> and <operational parameters>. The Behavioral Model of the equipment is represented by a user-defined, syntactically systemdirected C-program that establishes the relations among the defined sets of <process $>$ s, $<$ control signals $>$ and $<$ responses $>$. After consistency verification the system shows a pictorial representation of the result (Fig-3) in an interactive environment.

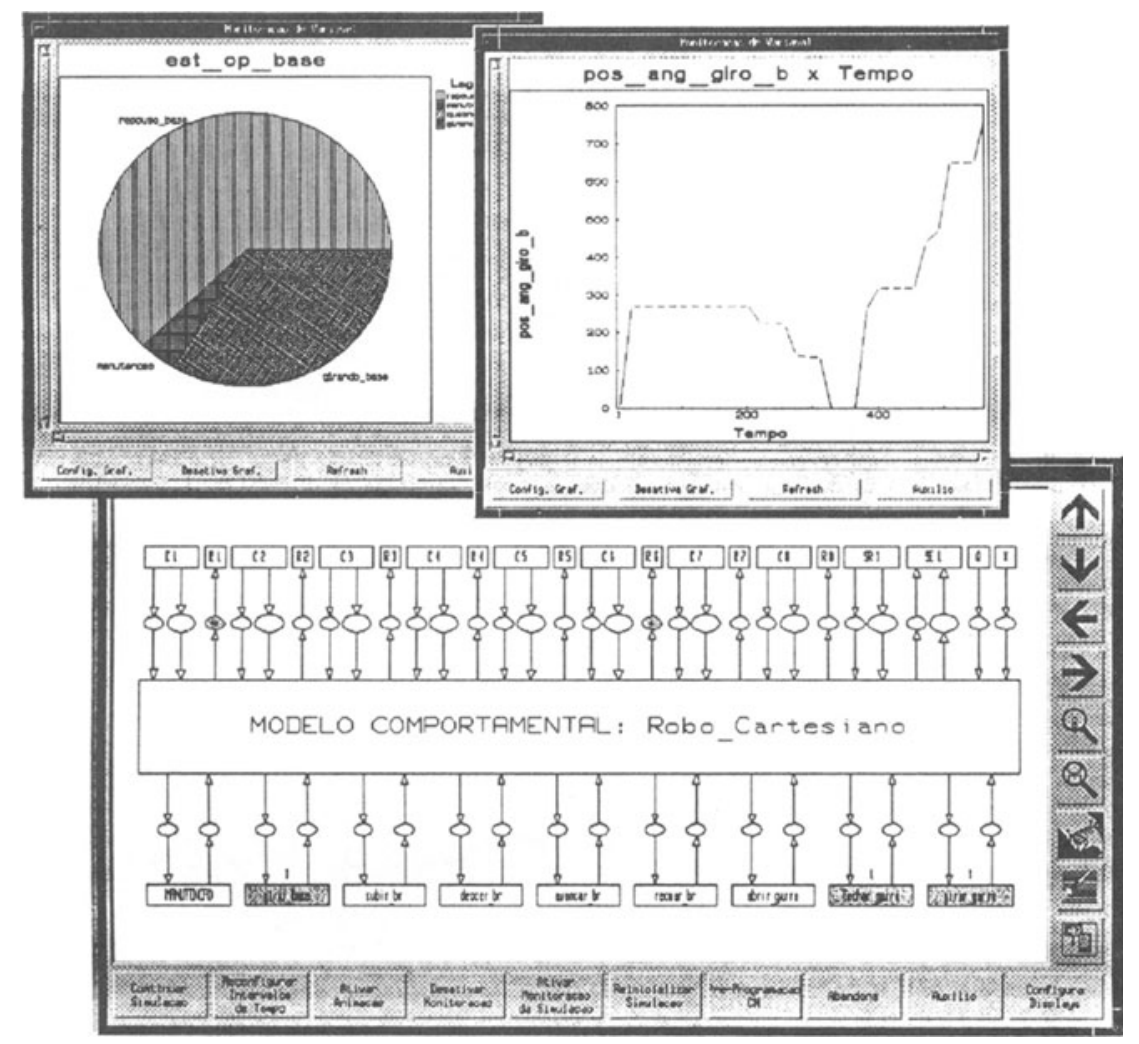

Fig-3: The behavioral model of a robot being validated in ANALYTICE

The user activates <process $>$ es of the equipment model by sending the related $<$ control signal $>$. The box or the corresponding <process $>$ turns to on during at time period computed in terms of the related <operational parameters $>$ (times, speeds, distances). After the computed period the <process $>$ box turns to off. The value of those variables defined as <monitoring variables $>$ in the equipment model can be monitored using simulated operation time as independent variable. The graphics of Fig-3 show the value of operation-state and baseposition monitoring variables. A validated behavioral model is called a CLASS.

It is possible to attach a geometrical and dynamic model to CLASSes in order to have an animation model of an equipment. Fig-4 shows the definition of the geometric model of the robot CLASS of Fig-3. 


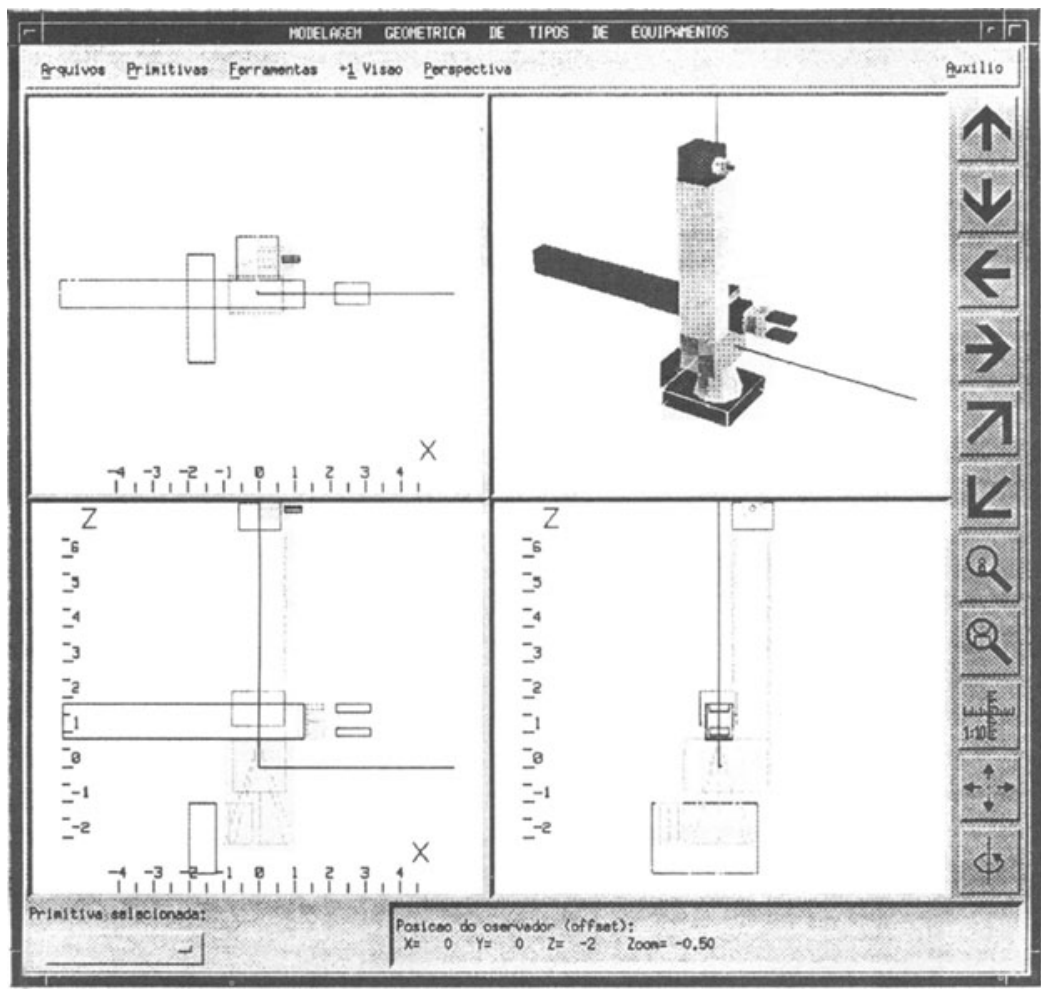

Fig-4: definition of a geometric model for the robot of Fig-3

A geometric model is defined by aggregating 3-D geometric modeling primitives. Each primitive is identified for utilization during cinematic model definition. The cinematic model is based on relations between the set of processes, the set of geometrical components of the geometric model and the set of monitoring variables of the behavioral model. The geometric and cinematic models will be validated by simulation. The set of monitoring variables will be updated by the behavioral model during simulation and the updated values are used at validation time to animate the equipment geometric components. It is possible to define stored program and simulate its execution. A CLASS with validated geometric and cinematic models is called a TYPE.

Equipment TYPE's occurrences can be aggregated to define manufacturing workstations. The behavior of workstations can be simulated for performance evalualion purpose. Validated workstation can be stored in the TYPEs Data Base. Manufacturing cells result from the aggregation of validated workstation TYPEs together with a material handling equipment recovered from TYPEs Data Base. Fig-5 shows a workstation defined in ANALYTICE by this aggregation procedure. The simulation at workstation level is driven by the execution of a control program at workstation level. Programs at this level are basically sequences of control signal to equipment of the workstation. 
Fig-5 shows a model of a workstation operating at $\mathrm{BOSCH} / \mathrm{Curitiba}$ resulting from the aggregation of equipment The human operator can execute several manufacturing processes, each corresponding to a specific part family.

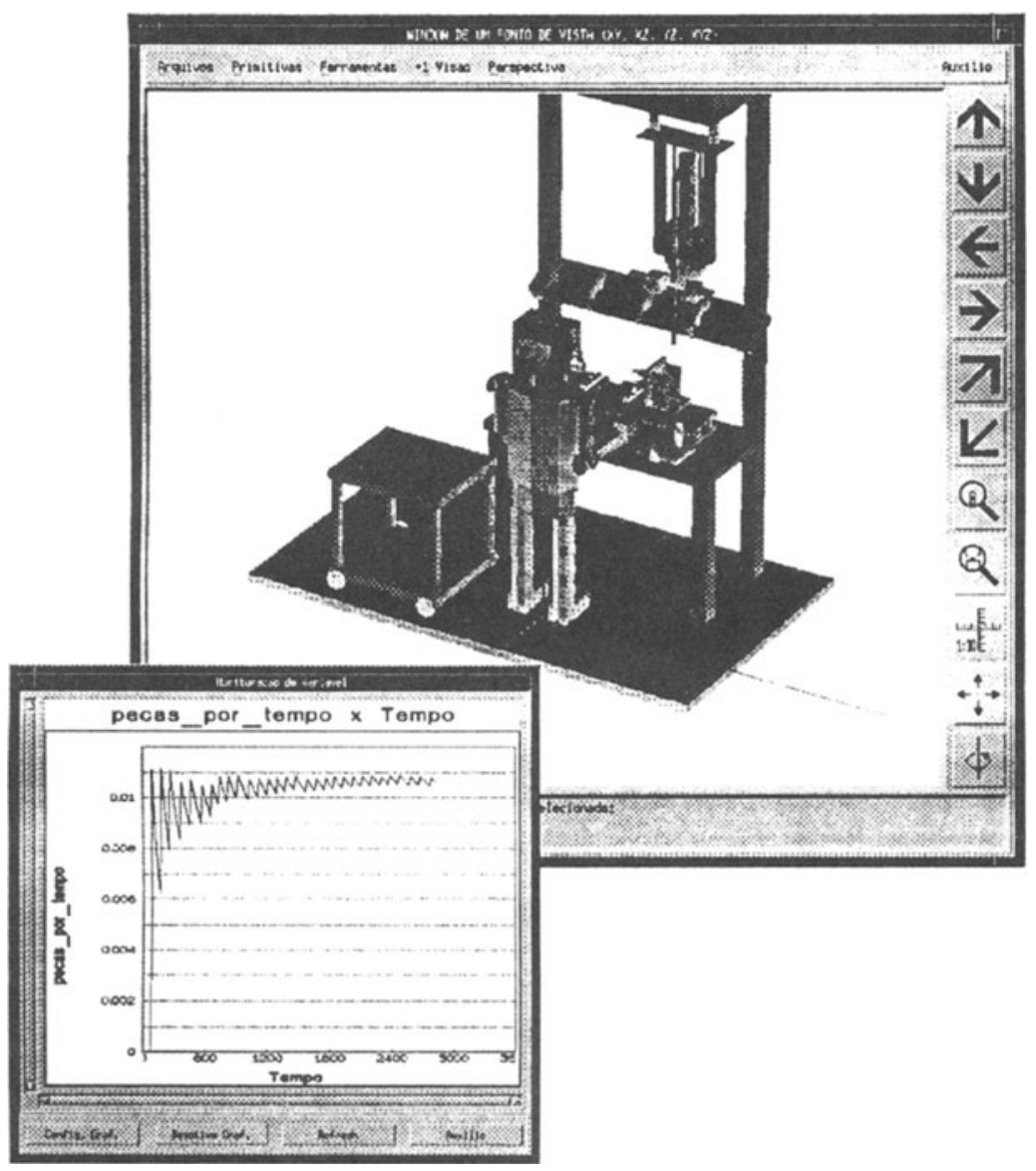

Fig-5: BOSCH manufacturing workstation modeled in ANALYTICE

The graphs shows the production rate versus simulated operation for one of the possible part type.

\section{THE EDUCATIONAL PROGRAM}

The educational program has been developed together with the software tool. It must be noticed that at the begin of the process no member of the staff has had any idea about FMS. 
The first goal was to obtain a clear understanding of the terminology and problems that would appear in FMS context. This understanding was necessary for the proposition of contents of disciplines and of student's work plans. All students at post-graduation level had a formal knowledge on data structures, C programming and UNIX operational system.

\subsection{Our Trial and Error Approach}

The initial research staft was formed by a research leader with Ph.D. level and systems performance evaluation expertise and three post-graduation students. The first internal documents show a great effort on terminology and basic concept's understanding and in the acquisition of an overall view of the relations among concepts. In order to formalize the ideas, a first publication was proposed to the students, with theme "The development cycle of FMS" ([1]). The resulting paper presented a top-down proposal of a macro-tasks sequence for FMS's development cycle: system specification, design, implementation and operation. Each macrotask in the sequence was detailed, identifying and establishing order relations over sub tasks. During this phase of the work terms and concepts like machine, process and routing flexbility, part types, process planning, part families, group technology, manufacturing cells, pallet types, machine selection, layout definition, scheduling policies, production costs, control part, $M H S, A G V, A S / R S, W I P$ and production mix, had to be understood, functionally related and time ordered. A rapid (about five months) system prototype was developed for identification of future implementation problems.

At the same time the skeletal of a curriculum was establishcd for providing formal education on manufacturing systems in general and FMS in particular. The guidelines for the curriculum were the need for mastering specifie topics on manufacturing systems together with specification and analysis techniques. The normal curriculum of the course was increased by disciplines on Petri nets ([2]) as formal specification tool, a discipline on performance evaluation of systems using timed Petri nets ([3], [4]). Two additional disciplines on FMS topics, one for generic conceptual and organizational definitions and a second discipline for modeling purpose were offered. Detailed theoretical study of some of the major problems (layout, control and group technology [5], [6], [7]) arising in FMS context were proposed as M.Sc. dissertations. A first altempt for a theoretical approach on scheduling failed.

The specification and implementation of the nucleus of the sortware ANALYTICE brought some insights on the needs of the educational program. The two disciplines on manufacturing systems were reduced to the one related to modeling and analysis of case studies. The students obtained conceptual data over FMS by reading internal documentation for terminological standardization and external technical publications for conceptual familiarization ([8], [9], [10], [11], [12], [13]). The reason for reducing the number of disciplines related with manufacturing systems was the well-known fact that students with formal knowledge are able to read technical papers on group technology, scheduling algorithms and concurrence problems in control of FMS. The Petri Nets discipline was expanded with a review on basic topics of set theory, relations, relations composition, mappings, equivalence relations, equivalence classes and graph theory.

The advances on the development of ANALYTYCE allowed us to propose new dissertation themes. A new attempt to simulate scheduling problems ([14]) was quite successful at theoretical level but failed in producing an environment to validate scheduling strategies. A more specific approach for simulaling FMS control problems ([15]) brought a 
pretty analysis of control specification languages at workstation and manufacturing cells levels. At that time ANALYTICE helped us to estimate implementation difficulties and development times for control implementation strategies. The major alternatives were Petri nets, Grafcet ([16]), Anteriority tables ([17]) and procedural languages. The decision was the utilization of procedural languages with mechanisms for describing concurrence, sequentialization and synchronization of processes. Four additional M.Sc. dissertations were used to develop the themes of production cost's analysis ([18]), modules for geometric and cinematic modeling of equipment ([19]), modeling and validation of material handling equipment ([20]) and quality control simulation ([21]). Three additional dissertations are at a final stage of development: the modeling of a real case manufacturing workstation ([24], modules for automatic layout definition at manufacturing cell level ([25]) and computation of the number of machines and pallets necessary to achieving gave production rates ([26]).

The educational program for new students was expanded introducing a second optional discipline on the topic of performance evaluation using Markov models. Finally, two new disciplines were offered for both new and older students in partnership with GMD/ Sankt Augustin: Compositional Data Objects ([22]) and High Level Petri Nets ([23]), dealing with formal specification and information modeling techniques.

\subsection{Analysis of the Implemented Education Program}

We believe that the executed education program gave the students a generalist view of the problems related with the specification and analysis of complex automated manufacturing systems. It is necessary to complement the program with a pratical experience of four to six months period in a real industrial environment. For the development of the next dissertations involving modeling and analysis of manufacturing systems it will be required the acquisition of real data in the industry. A first attempt in this direction is being made ([24]).

For an education program directed to people already working in the industry it seems that a review of formal modeling and analysis techniques is necessary. This review can be executed in parallel with a discussion of topics on new manufacturing systems, working the relations between the formal techniques and the pratical problems. A second step of the education program is based on case studies with the utilization of a manufacturing systems simulator. This two-phases program is depicted in fig- 6 .

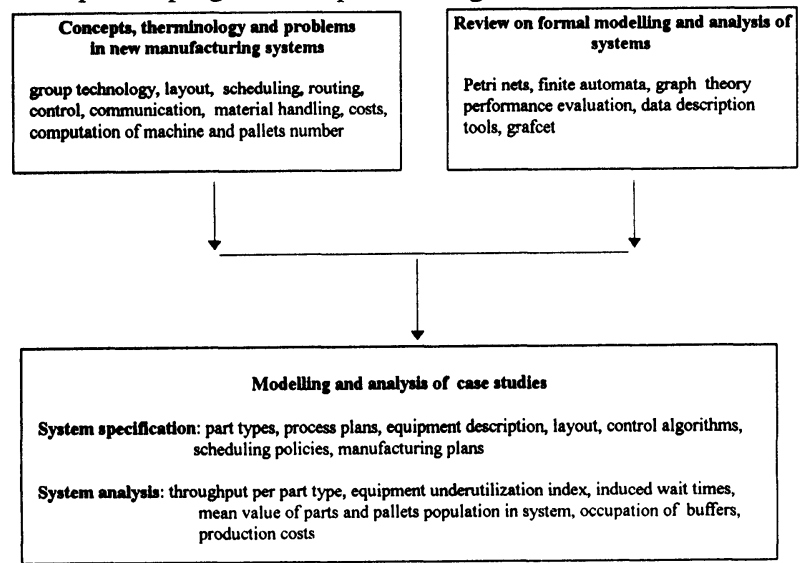

Fig-6: Skeletal of a continuous education program in new manufacturing systems 


\section{CONCLUSION}

It is obvious that the actual education program has been strongly influenced by the software development needs. It must be noticed, however, that the education in formal disciplines together with the utilization of the resulting software for modeling and analysis objectives has brought an automated manufacturing mentality to the students. A program for visiting automated industries and/or dealers of industrial automation equipment in Europe has been partially executed by the students, giving some insight into the real industrial environment. For a modern education program directed to engineers working in a production environment, the utilization of a simulator of manufacturing system is of primary need. Due to the related cost and time it is not possible to develop skill in design and alternative analysis working over real manufacturtng systems. At the other hand, as simulators for complex manufacturing systems are normally complex software packages, a formal understanding of the objects being manipulated and of the resulting performance curves is necessary.

\section{ACKNOWLEDGMENTS}

To all my students ([5],[6],[7],[14],[15],[18],[19], [20], [21], [24], [25], [26]) for the entusiasm during the software developmnent,specially to Omar Achraf, Cesar Godoy and Lissandro Bassani that implemented the nucleus of ANALYTICE working with uncomplete specifications.

\section{REFERENCES}

[1] Künzle, A., Souzu A. \& Stadzisz P.: Uma proposta de ciclo de vida para Sistemas Flexíveis de Manufatura, SUCESU, Anais do XXII Congresso Nacional de Informática, São Paulo, 1989, pp. 736-750.

[2] Reisig, W.: Petri Nets: an introduction, EATCS Monographs on Theoretical Computer Science, v. 4, Springer Verlag, Berlin, 1985.

[3] Tazza, M.: Análise quantitativa de sistemas, III EBAI, Curitiba 1988.

[4] Tazza, M.: Quantitative Analysis of a Resource Allocation Problem: A Net Theory Based Proposal, in Voss et al. (eds.) APN 87, Concurrency and Nets, Springer Verlag, 1987, pp. 511-532.

[5] Studzisz, P.: Especifcação de um ambiente computacional para auxílio ao projeto do arranjo físico de sistemas flexiveis de manufatura. Dissertação de mestrado, CPGEI / CEFET-PR, Curitiba, ag. 1990.

[6] Künzle, L. A.: Controle de sistemas flexíveis de manufatura - especifcação dos níveis equipamento e estação de trabalho, Dissertação de mestrado, CPGEI / CEFET-PR, Curiliba, ag. 1990.

[7] Souza, J. H. F.: Tecnologia de Grupo: algoritmos e ferramenta gráfica, Dissertação de Mestrado, CPGEI / CEFET-PR, Curitiba, ag. 1990.

[8] Buzacott J. A. \& Yao D. D.: Flexible Manufacturing Systems: a Rewiew of Analytical Models. Managment Science, v. 32, n. 7, Jul. 1986, pp. 890-905.

[9] Kusiak, A.: Flexible Manufacturing Systems: a structural approach, International Journal of Production Research, v. 23, n. 6, 1985 pp. 1057-1073. 
[10] Gallagher,C.C.: \& Knight,W.A.: Group Technology Methods in Manufacture, Ellis Horwood Limited, 1st ed. England, 1986.

[11] Carrie, A.: Simullation of Manufacturing Systems, John Wiley \& Sons, Chichester, 1988.

[11] Valette, R.: Nets in Production Systems, in: Rozemberg. G. (ed). Advanced Course on Petri Nets. Bad Honnef, Springer Verlag, 1987,pp.191-217.

[12] Browe, J. et al.: Classifcation of flexible manufacturing systems, The FMS Magazine, ap. 1984, pp. 114-117.

[13] Conway, R. W., Maxwell, W. L. \& Müler, L. W.: Theory of Scheduling, AddisonWesley, Reading, Mass, 1967.

[14] Sautter F.T.: O problema de escalonamento em Sistemas Fleriveis de Manufatura. Dissertação de Mestrado, CPGEI/CEFET- PR, Curiliba, 1993.

[15] Tacla C.A.: Controle de Sistemas Flexíveis de Manufatura, Especifcação do nível estação. Dissertação de Mestrado, CPGEI/ CEFET-PR, Curitiba, ag. 1993.

[16] David, R. \& Alla, H.: Petri Nets and Grafcet, Prentice Hall, NewYork, 1992.

[17] Deschanel, F.: Pilotage d'une Cellule Flexible d"Usinage. These de Doctorat, Universite de Franche-Comte, 1989.

[18] Gallotta, A.: Especifcação e implementação de Módulo de Análise de Custos em FMS. Dissertação de Mestrado CPGEI / CEFET-PR, Curitiba, mar. 1994.

[19] Contesini, M.: Interface para Projeto Gráfico de Equipamentos de Manufatura, Dissertação de Mestrado, CPGEI / CEFET-PR, Curitiba, dez. 1994.

[20] Angonese, V.: Modelagem de Equipamentos de Manuseio de Materiais em ANALYTICE, Dissertação de Mestrado, CPGEI / CEFET PR, Curitiba, nov. 1994.

[21] Lugo, C. J.: Simulação do Controle de Qualidade em Sistemas Flexíveis de manufatura, Dissertação de Mestrado, CPGEI / CEFET-PR, Curitiba, set. 1994.

[22] Durchholz, R. \& Richter, G.: Compositional Data Structures, The IMC/IMCL Reference Manual, 1. Wiley, 1992.

[23] Meta Software Corporation: Design/CPN, Internal Functions Programmer's Reference, Version 2.0, Meta Software Corporation 1993.

[24] Nied, A.: Modelagem e Análise de uma Estação de Trabalho em ANALYTICE, Dissertação de Mestrado, CPGEI/CEFET-PR, Curitiba, conclusão prevista jun. 1995.

[25] Gallotta, M.P.: O problema de dimensionamento em FMS, Dissertação de Mestrado, CPGEI/CEFET-PR, Curitiba, conclusão prevista para jun. 1995.

[26] Tsunoda, D.: Ambiente para definição automática de arranjo físico em ANALYTICE, Dissertação de Mestrado, CPGEI/CEFET-PR, Curitiba, conclusão prevista para jun. 1995. 